Bangladesh J. Sci. Res. 27(1): 11-25, 2014 (June)

\title{
APPLICATION OF BIOCHAR AND FATE OF SOIL NUTRIENTS
}

\author{
K. T. Khan, M. T. A. Chowdhury and S. M. Imamul Huq* \\ Bangladesh-Australia Centre for Environmental Research, Department of Soil, Water \\ and Environment, University of Dhaka, Dhaka-1000, Bangladesh
}

\begin{abstract}
An in vitro incubation study was conducted with soil having seven applications of different treatments of biomass and biochar including a control. The biochar and biomass were applied at a rate of $5 \mathrm{t} / \mathrm{h}$ a and incubated at field moisture condition for 30, 60 and 90 days individually in different pots. Total organic carbon (C), total nitrogen, phytoavailable nitrogen $(\mathrm{N})$, phosphorus $(\mathrm{P})$, sulfur $(\mathrm{S})$ and potassium $(\mathrm{K})$ were determined at the end of each incubation period. Total soil organic carbon (SOC), showed a substantial declining trend in all the soils - more prominent in the biochar treated soils than its corresponding biomass treated soils. The $\mathrm{pH}$, total $\mathrm{N}$, phytoavailable $\mathrm{N}, \mathrm{P}, \mathrm{K}$ were substantially higher in the biochar treated soils irrespective of the incubation days compared to the biomass treated soils. Conversely, the available $S$ contents of the biochar treated soils were lower than that of biomass treated soils. The effect of biochar on these nutrients vis-à-vis soil health is discussed.
\end{abstract}

Key words: Soil nutrients, biochar, soil health

\section{Introduction}

Biochar, a carbon-rich by-product of biological origin produced by pyrolysis, is progressively being considered by scientists and policy makers for its impending role in carbon sequestration, reducing greenhouse gas emissions, renewable energy, waste mitigation, and as soil amendment.

There is a strong interest in stabilizing the atmospheric abundance of $\mathrm{CO}_{2}$ and other greenhouse gases (GHGs) to mitigate the risks of global warming (Kerr 2001, Kluger 2007, Chapman and Walsh 2007), and it is very crucial for countries like Bangladesh where climate change is likely to impact upon the environment and eventually cause disturbed crop production leading the food security to a risk. At present, one of the plausible methods for the large scale carbon sequestration is sequestration with biochar (Woolf 2008, Woolf et al. 2010) that demonstrate that sustainable biochar production and its soil application have the potential to make a substantial contribution to mitigating climate change.

The method of using charcoal to enhance the soil fertility and productivity has been practiced in the Amazon basin about 2500 years ago. According to Lehmann and Joseph (2009), biochar is becoming a popular alternative to organic amendments that is being applied to soils to increase and sustain soil productivity. The use and functions of biochar

*Corresponding author: <imamhuq@hotmail.com>. 
in soils have been recently reviewed by Sohi et al. (2010) and potential mechanisms of achieving agricultural benefits by biochar - soil application by Atkinson et al. (2010). Biochar alters soil structure, increases among others, water retention capacity, CEC, sorption capacity, base saturation percentage, surface area, microbial activity, $\mathrm{pH}$ of acid soils etc. That is why biochar is gaining huge acclamation of the environmentalists, scientists and researchers nowadays to mitigate climate change and to enhance nutrient management.

On the other hand, the fact that soil organic matter (SOM) is the heart of soil cannot be overlooked as it is a vital source of energy and nutrients for the soil macro- and microorganisms and the plants as well. SOM is important to soil fertility because it contains at least $95 \%$ of the total nitrogen and sulfur along with 20 to $75 \%$ of phosphorus in the soil surface (Steiner et al. 2007). Soil organisms, including micro organisms, use soil organic matter as food. As they break down the organic matter, any excess nutrients (N, P and S) are released into the soil in the forms that plants and organisms can use (Web 1).

Application of biochar carbon allows cycling of nutrients back into the agricultural soils and sequestering carbon in a recalcitrant form (Steiner 2010). However, the effect of biochar on soil nutrient transformations has not been adequately studied (DeLuca et al. 2009). In particular, understanding characteristics of biochars to avoid ecotoxicological impacts, understanding the effects of biochar on nutrient and contaminant (e.g. heavy metals) behavior and transport, the effects of aging and the influence of feedstock and pyrolysis conditions on key properties are some of the areas that require attention. Moreover, there are some questions that still need to be answered. These are:

- The availability of nutrients, especially nitrogen, with the high adsorption capacity of soils after biochar application as the nutrients may become immobilized (DeLuca et al. 2009);

- Biochar is altered during pyrolysis and form 'benzene- type' ring structures that are very resistant to attack by the microorganisms (Web 2). As a result, microorganisms do not get source for carbon and, thus, mineralization rates slow down. So, the rate of mineralization process and source of nutrients for microorganisms after biochar application still remains unsolved;

- The reason and actual mechanism behind the high availability of nutrients after biochar application in soil;

- Effectiveness of biochar to soil quality and health due to the above reasons.

Considering all these facts, it is plausible to look into the facts that how biochar affects the soil nutrients via-á-vis the traditional method of maintaining soil nutrients by application of undecomposed, partially decomposed or decomposed organic matters. Therefore, the present work has been carried out with following objectives in mind - the 
nutrient release after application of equal rate of biomasses and their corresponding biochars in soil.

\section{Materials and Methods}

Soil sampling site: Surface soil $(0-15 \mathrm{~cm})$ was collected from vegetable fields in Jagir Dighulia village, Atigram union, Manikganj sadar, Manikganj District. The geo-location of the sampling site is $23^{\circ} 51.884 \mathrm{~N}$ and $90^{\circ} 06.219 \mathrm{E}$ (Fig. 1).The soil is a non calcareous grey floodplain belonging to the Melandaha series.

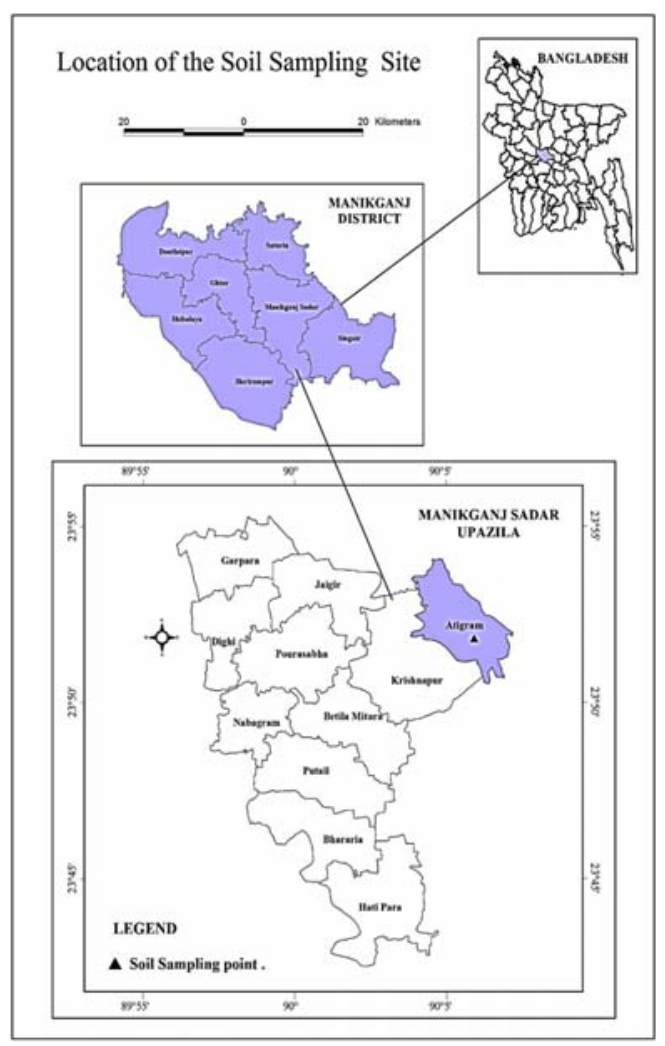

Fig. 1. GPS-GIS based location map of the soil sampling site.

Sample collection and preparation: The collected soil samples were dried in air 4 to 5 days by spreading in a thin layer on a clean piece of brown paper after being transported to the laboratory. Visible roots and debris were removed from the sample and discarded. To hasten the drying process, the samples were exposed to sunlight. After air-drying, a portion of the sample containing the larger aggregates was ground by gently crushing with a wooden hammer. Ground samples were passed through a $2 \mathrm{~mm}$ stainless steel sieve. The sieved samples were then mixed thoroughly and stored in labeled plastic containers until required for various physical analyses. Another portion of the soil 
samples ( $2 \mathrm{~mm}$ sieved) were further ground and passed through a $0.5 \mathrm{~mm}$ sieve. The sieved samples were mixed thoroughly and stored as above until required for chemical and physico-chemical analyses. The bulk soil samples collected for incubation study were air-dried, cleared of debris and crushed to reduce the size of large clods. The crushed soil samples were screened through a $5 \mathrm{~mm}$ sieve.

Biochar and biomass sample preparation: Three different types of biomasses, i.e. rice husk, rice straw and saw dust (Table 1) were procured locally. The biomasses were properly dried in oven at $\sim 80^{\circ} \mathrm{C}$ (Only rice straw was washed and dried and then ground). Then, a portion of these biomasses were sieved through a $0.25 \mathrm{~mm}$ sieve for routine analyses. Another portion was kept to produce biochar (Mahmud et al. 2014). Rest of the portion was stored for incubation study. After making biochars from each of the biomasses (Table 1) they were sieved through a $0.25 \mathrm{~mm}$ sieve. This $0.25 \mathrm{~mm}$ sieved biochars were stored for routine analyses. Rest of the samples was stored for incubation study.

Table 1. List of biomasses and biochars with designation.

\begin{tabular}{lccc}
\hline Biomass & Designation & Biochar from the corresponding biomass & Designation \\
\hline Rice husk & BM1 & Biochar 1 & BC1 \\
Rice straw & BM2 & Biochar 2 & BC2 \\
Saw dust & BM3 & Biochar 3 & BC3 \\
\hline
\end{tabular}

In vitro incubation experiment: In order to study the fate of soil nutrients as affected by the application of biochar, an in vitro incubation experiment was performed using seven different treatments (Table 2). The total incubation period was 90 days portioned into three intervals, viz., 30, 60 and 90 days. So, a total number of 21 pots were used in the incubation study.

Pot preparation: Half kilogram sized plastic pots were procured from local market. These were washed properly with water and dried at ambient temperature of the laboratory and stored. Each pot was marked in accordance with the treatments. Then, 400 $\mathrm{g}$ of air dried $5 \mathrm{~mm}$ sieved soil sample were taken into each of the plastic pots and $1 \mathrm{~g}$ each of either biomass or biochar was thoroughly mixed with the soil. The soils were then incubated at field moisture condition for 30, 60 and 90 days, respectively.

Table 2. Treatment description and symbol.

\begin{tabular}{llll}
\hline Treatment no. & Treatment symbol & Description & Rate of application \\
\hline 1. & $\mathrm{~T}_{\mathrm{C}}$ & Control & None \\
2. & $\mathrm{~T}_{\mathrm{BM} 1}$ & Rice husk (BM1) & 5 tons/ha \\
3. & $\mathrm{~T}_{\mathrm{BM} 2}$ & Rice straw (BM2) & 5 tons/ha \\
4. & $\mathrm{~T}_{\mathrm{B} 33}$ & Saw dust (BM3) & 5 tons/ha \\
5. & $\mathrm{~T}_{\mathrm{BC} 1}$ & Biochar from rice husk (BC1) & 5 tons/ha \\
6. & $\mathrm{~T}_{\mathrm{BC} 2}$ & Biochar from rice straw (BC2) & 5 tons/ha \\
7. & $\mathrm{~T}_{\mathrm{BC} 3}$ & Biochar from saw dust (BC3) & 5 tons/ha \\
\hline
\end{tabular}


Collection of sample at the end of each incubation: After incubation, the soil in each of the pots was mixed thoroughly for ensuring uniform sampling. Thereafter, the soil samples from each of the pots were collected randomly for further analyses.

Laboratory analyses: Various physical, chemical and physico-chemical properties of the soil as well as the biochar and biomass were analyzed in the laboratory. The particle size analysis of the soil sample was done by Hydrometer method (Huq and Alam 2005). $\mathrm{pH}$ of soil (pre- and post-experiment) and of biochar and biomass were determined by using a pH meter at a soil : water ratio of $1: 2.5$ for soil and a ratio of $1: 15$ for biochars and biomasses. Organic carbon of the soil (pre- and post-experiment) and of biochar and biomasses were determined by wet oxidation method of Walkley and black as described in Huq and Alam (2005). Total nitrogen of the samples was determined by steam distillation of the Kjeldahl digest (Jackson 1962). Available nitrogen was determined by extracting samples with $1 \mathrm{M} \mathrm{KCl}$ and then extracts were distilled with $40 \% \mathrm{NaOH}$ which gave off ammonia that were collected on a $2 \%$ boric acid-mixed indicator solution. The distillate was titrated against $0.02 \mathrm{M}$ sulfuric acid $\left(\mathrm{H}_{2} \mathrm{SO}_{4}\right)$ as described in Huq and Alam (2005). The available phosphorus of the samples were determined by extracting samples using Bray and Kurtz method (for $\mathrm{pH}<6.0$ ) and Olsen method (for $\mathrm{pH}>6.0$ ) and then the extracts were used to estimate P colorimetrically by following the blue color method using ascorbic acid by spectrophotometer at $880 \mathrm{~nm}$. The available $\mathrm{S}$ was determined by extracting the samples with calcium dihydrogen phosphate monohydrate $\left[\mathrm{Ca}\left(\mathrm{H}_{2} \mathrm{PO}_{4}\right)_{2}\right.$. $\mathrm{H}_{2} \mathrm{O}$ ] and then the extracts were analyzed with a spectrophotometer at $420 \mathrm{~nm}$. The available $\mathrm{K}$ of the samples was determined by a flame analyzer after extracting the soil samples (pre- and post-experiment) with $1 \mathrm{M}$ ammonium acetate at $\mathrm{pH}$ 7.0. Total $\mathrm{P}$ content of the soil and biomass and biochar samples were determined colorimetrically using a spectrophotometer at $490 \mathrm{~nm}$ by developing yellow color with vanadomolybdate after the extract was collected by digesting with ternary acid mixture (Huq and Alam 2005). Total potassium content of the soil, biomass and biochar samples were determined by a flame analyzer after digesting the samples with ternary acid mixture. Total sulphur content was determined turbidimetrically by a spectrophotometer at $420 \mathrm{~nm}$ after digesting the samples with IM HCl.

Data analysis: All data were statistically analyzed by using Microsoft Excel 2010 and/or MINITAB (Version 16.2).

\section{Results and Discussions}

Soil properties: The various properties of the soil used in this experiment were analyzed in the laboratory and are presented in Table 3. 
Table 3. Physical, chemical and physico-chemical properties of soil.

\begin{tabular}{ll}
\hline Properties & Value \\
\hline \% sand & 13.9 \\
\% silt & 74.1 \\
\% clay & 12.0 \\
Textural class & Silt loam \\
\% Moisture & 13.3 \\
$\mathrm{pH}$ & 5.6 \\
Total organic C $(\%)$ & 0.3 \\
Total N (\%) & 0.03 \\
Total P (mg/kg) & 23.1 \\
Total S $(\mathrm{mg} / \mathrm{kg})$ & 453.7 \\
Total $\mathrm{K}(\mathrm{mg} / \mathrm{kg})$ & 122.7 \\
Available N $(\mathrm{mg} / \mathrm{kg})$ & 40.0 \\
Available P $(\mathrm{mg} / \mathrm{kg})$ & 5.2 \\
{$\left[\mathrm{Ca}\left(\mathrm{H}_{2} \mathrm{PO}\right)_{2} \cdot \mathrm{H}_{2} \mathrm{O}\right]$ extractable S $(\mathrm{mg} / \mathrm{kg})$} & 10.0 \\
$\mathrm{NH} \mathrm{H}_{4} \mathrm{OAc} \mathrm{extractable} \mathrm{K}(\mathrm{mg} / \mathrm{kg})$ & 28.9 \\
$\mathrm{CEC}(\mathrm{Cmol} / \mathrm{kg})$ & 14.7 \\
$\mathrm{C}: \mathrm{N}$ & $10: 1$ \\
\hline
\end{tabular}

Biochar and biomass properties: The samples of biochar and biomass included in this experiment were analyzed in the laboratory for chemical and physico-chemical properties and the results are presented in Table 4.

Table 4. Chemical and physico-chemical properties of biochars and biomasses.

\begin{tabular}{lcccccc}
\hline \multirow{2}{*}{ Properties } & \multicolumn{3}{c}{ Biomass } & \multicolumn{3}{c}{ Biochar } \\
\cline { 2 - 7 }$\%$ moisture & BM 1 & BM 2 & BM 3 & BC 1 & BC 2 & BC 3 \\
\hline pH & 4.67 & 3.7 & 22.1 & - & - & - \\
Total organic C (\%) & 6.6 & 7.6 & 6.1 & 7.5 & 10.5 & 6.7 \\
Total N (\%) & 16.8 & 51.2 & 42.6 & 32.8 & 55.6 & 19.7 \\
Total P (\%) & 0.76 & 0.29 & 0.17 & 0.52 & 0.30 & 0.17 \\
Total S (\%) & 0.86 & 0.04 & 0.11 & 1.70 & 0.15 & 0.48 \\
Total K (\%) & 9.0 & 114.2 & 22.3 & 20.7 & ND $^{*}$ & ND $^{*}$ \\
CEC (Cmol/kg) & 0.75 & 0.26 & 0.29 & 0.20 & 0.71 & 0.78 \\
C/N ratio & 17.1 & 12.9 & 16.1 & 20.2 & 16.0 & 17.5 \\
\hline
\end{tabular}

${ }^{*} \mathrm{ND}=$ Not detectable

Soil $p H$ : It is observed that after the application of biomasses and biochars, change in $\mathrm{pH}$ of the soils was similar to the control soil $\left(\mathrm{T}_{\mathrm{C}}\right)$, i.e. initially a slight decrease at 30 days of incubation followed by an increase at 60 days of incubation and again a decline at 90 days of incubation (Fig. 2). The initial decrease at 30 days and increase at 60 days in $\mathrm{pH}$ of soils could possibly be due to the complex chemistry of the submerged soils. 
According to Motomura (1962) and Ponnamperuma (1965), when an aerobic soil is submerged, its $\mathrm{pH}$ decreases during the first few days, reaches a minimum, and then increases asymptotically to a fairly stable value of 6.7-7.2 a few weeks later. However, in all the cases, the $\mathrm{pH}$ of biochar treated soils was greater than that of the biomass treated soil and even greater than the control soil. This could be due to the alkaline nature of the biochars (Table 4). As nutrient availability depends on soil $\mathrm{pH}$, this $\mathrm{pH}$ change by biochar application can change the nutrient availability in soil and sometimes very high $\mathrm{pH}$ can cause micronutrient deficiency in soil. Wardle et al. (2008a) suggested alkaline biochar may increase the $\mathrm{pH}$ of acidic soils. Fowles (2007) showed a change in soil pH to a more neutral pH, especially in acidic soil after biochar application. Van Zwieten et al. (2010) demonstrated that the carbonate concentration of biochar facilitates liming in soils and can raise soil $\mathrm{pH}$ of neutral or acidic soil. According to Chan et al. (2007), the concentration of carbonate can vary from 0.5 to $33 \%$ depending on starting condition and biomass materials.

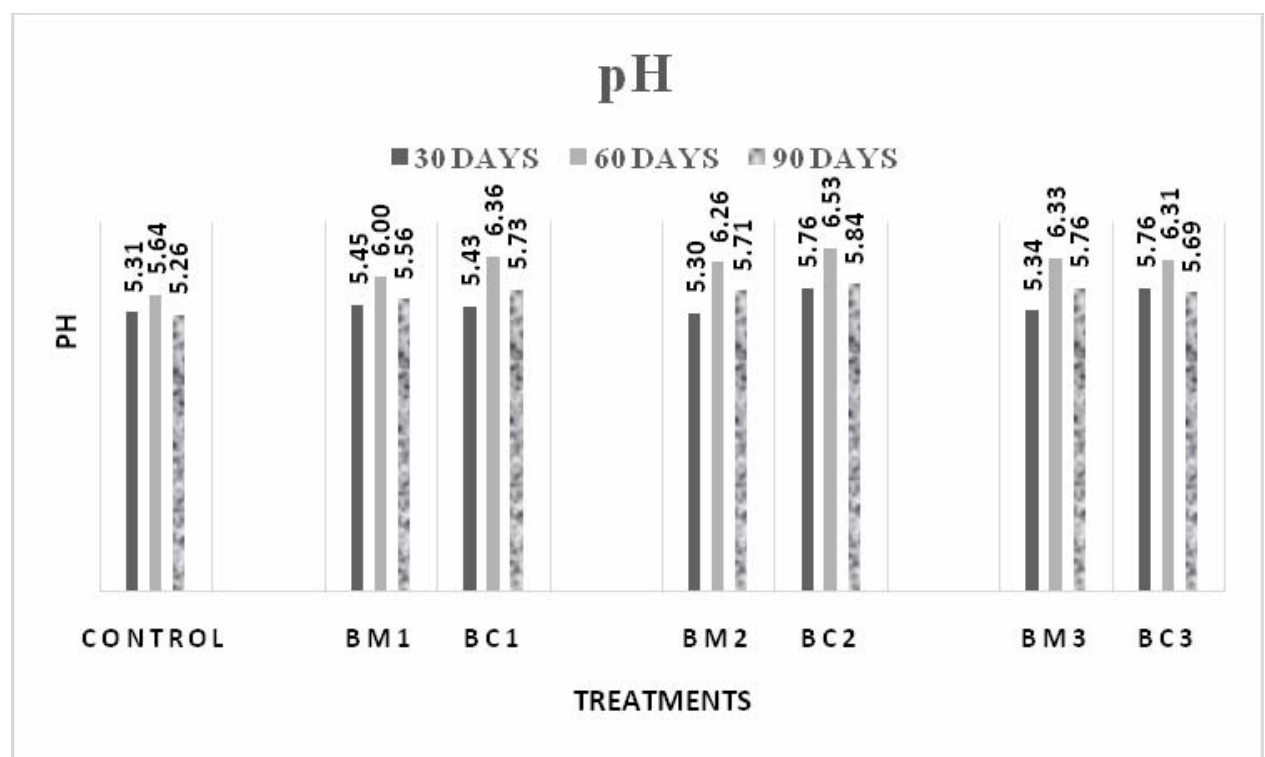

Fig. 2. Effect of biochar and biomass applications on soil $\mathrm{pH}$ at different incubation days.

Total organic carbon: After instant increase of the total soil organic carbon (SOC) just after application of the treatments, biomass and biochar treated soils showed a consistent decreasing trend $(\mathrm{p}>0.05)$ at 30, 60 and 90 days of incubation (Table 5). However, control soil $\left(\mathrm{T}_{\mathrm{C}}\right)$ responded differently. The total SOC of the untreated soil increased at 30 days of incubation then decreased during the rest of the incubation period. The decline could have happened as there was no organic matter supplied to the control soil. The decreasing total SOC in the biochar treated soils could be due to the accelerated 
decomposition rate of the organic carbon by micro-organisms after application of fresh biochar. Sohi et al. (2010), Lehmann and Sohi (2008) and Wardle et al. (2008a and 2008b) assumed that it is still under speculation and warrants further investigation whether biochar application stabilizes soil $\mathrm{OM}$ and soil C, or results in priming. Steinbeiss et al. (2009) found that the total carbon content of soils decreased after application of biochar in controls and all treatments over incubation time and concluded that the relative amount of carbon remaining in the soils after biochar incubation only depended on the type of biochar added but did not depend on soil type itself or any interaction between soil type and biochar type. Similar observations have been made in the present case. The biochar made from rice husk sequestered higher carbon than the other two sources. Wardle et al. (2008a) suggested that the rapid introduction of readily available nutrients and small amounts of labile $\mathrm{C}$ retained in biochar could promote mineralization of SOM, especially in nutrient - limited environment. Additionally, alkaline biochar may increase the $\mathrm{pH}$ of acidic soils and subsequently stimulate microbial activity thereby further promoting mineralization or decomposition of existing SOM. Our findings also corroborate to this observation.

Table 5. Total soil organic carbon (SOC) after biochar and biomass applications at different incubation days.

\begin{tabular}{|c|c|c|c|c|c|c|c|}
\hline \multirow{3}{*}{$\begin{array}{l}\text { Incubation } \\
\text { days }\end{array}$} & \multicolumn{7}{|c|}{ Total soil organic carbon (\%) } \\
\hline & \multicolumn{2}{|l|}{ Control } & \multicolumn{2}{|c|}{ Biomass } & \multicolumn{3}{|c|}{ Biochar } \\
\hline & $\left(T_{C}\right)$ & $\mathrm{T}_{\mathrm{BM} 1}$ & $\mathrm{~T}_{\mathrm{BM} 2}$ & $\mathrm{~T}_{\mathrm{BM} 3}$ & $\mathrm{~T}_{\mathrm{BC} 1}$ & $\mathrm{~T}_{\mathrm{BC} 2}$ & $\mathrm{~T}_{\mathrm{BC} 3}$ \\
\hline 30 & 1.08 & 1.09 & 1.01 & 1.08 & 0.98 & 0.77 & 0.82 \\
\hline 60 & 0.54 & 0.56 & 0.41 & 0.53 & 0.48 & 0.52 & 0.46 \\
\hline 90 & 0.25 & 0.51 & 0.61 & 0.49 & 0.36 & 0.43 & 0.45 \\
\hline
\end{tabular}

Total and available $N$ : The total nitrogen of the soils with all the treatments increased from that of initial level during the entire incubation period, including very slight increase in soil with control treatment $\left(\mathrm{T}_{\mathrm{C}}\right)$. In the first sampling (i.e. 30 days of incubation), the total $\mathrm{N}$ content of all the treated soils was stable at the background level (i.e. $0.03 \% \mathrm{~N}$ ), except in the rice husk treated $\left(\mathrm{T}_{\mathrm{BM} 1}\right)$ soils that showed slight decrease (i.e. $0.02 \% \mathrm{~N}$ ). In the second sampling (i.e. 60 days of incubation) the magnitude of total $\mathrm{N}$ increase was from 0.04 to $0.05 \%$ for biomass treatments and 0.04 to $0.15 \%$ for biochar treatments. In the last sampling (i.e. 90 days of incubation), the magnitude of total $\mathrm{N}$ increase was from 0.08 to $0.15 \%$ for biomass treatments and 0.04 to $0.07 \%$ for biochar treatments (Table 6 ). 
It is clear that the changes in total nitrogen status of control soil as well as biomass and biochar treated soils showed similar trend, i.e. a continuous increase. However, saw dust biochar treated soil behaved exceptionally. After increasing at 60 days, the total $\mathrm{N}$ decreased at 90 days of incubation in this soil. At 30 days of incubation, the total nitrogen content of biomass and biochar treated soils was almost close. But at 60 days of incuba-

Table 6. Total nitrogen in soil after biochar and biomass applications at different incubation Days.

\begin{tabular}{llllllll}
\hline \multirow{2}{*}{$\begin{array}{l}\text { Incubation } \\
\text { days }\end{array}$} & \multicolumn{9}{c}{ Total nitrogen (\%) } \\
\cline { 2 - 8 } & Control & $\mathrm{T}_{\mathrm{BM} 1}$ & $\mathrm{~T}_{\mathrm{BM} 2}$ & $\mathrm{~T}_{\mathrm{BM} 3}$ & $\mathrm{~T}_{\mathrm{BC} 1}$ & $\mathrm{~T}_{\mathrm{BC} 2}$ & $\mathrm{~T}_{\mathrm{BC} 3}$ \\
\cline { 2 - 8 } & $\left(\mathrm{T}_{0}\right)$ & 0.02 & 0.03 & 0.03 & 0.03 & 0.03 & 0.03 \\
60 & 0.03 & 0.05 & 0.04 & 0.04 & 0.04 & 0.06 & 0.12 \\
90 & 0.03 & 0.15 & 0.09 & 0.08 & 0.04 & 0.06 & 0.07 \\
\hline
\end{tabular}

tion, the total $\mathrm{N}$ content of biochar treated soils was higher than that of biomass treated soil, whereas at 90 days of incubation, the total $\mathrm{N}$ content of biomass treated soils was higher than that of biochar treated soils. This could happen as a result of decreasing carbon content. Microorganisms might have used up the readily available carbon as the source of their energy more quickly than it could for the nitrogen. It needs to be mentioned here that the $\mathrm{C} / \mathrm{N}$ ratios of the biochars and biomasses were quite large (Table 4). This rapid utilization of $\mathrm{C}$ is also evident from the continuous decreasing $\mathrm{C} / \mathrm{N}$ ratio of the soil with time. Nigussie et al. (2012) found that the total soil nitrogen increased after the application of maize stalk biochar which they thought could be resulted from presence of high amount of carbon and nitrogen in maize stalk. According to Chan and $\mathrm{Xu}$ (2009), a C/N ratio above 20 for organic substrate is considered the critical limit above which immobilization of $\mathrm{N}$ by microorganisms occur. Our findings also corroborate to these observations.

The available $\mathrm{N}$ of the soils varied at different incubation days. In the first sampling (i.e. 30 days of incubation), the available $\mathrm{N}$ of the soils with all treatments decreased (ranging from 19.88 to $27.71 \mathrm{mg} / \mathrm{kg}$ for biomass treatments and 17.79 to $27.21 \mathrm{mg} / \mathrm{kg}$ for biochar treatments) from that of the background level of the soil (i.e. $40 \mathrm{mg} / \mathrm{kg}$ ). In the second sampling (i.e. 60 days of incubation), the available $N$ in soils with control $\left(\mathrm{T}_{\mathrm{C}}\right)$, biomass $\left(\mathrm{T}_{\mathrm{BM} 1}, \mathrm{~T}_{\mathrm{BM} 2}\right)$, and biochar $\left(\mathrm{T}_{\mathrm{BC} 1}\right.$, and $\left.\mathrm{T}_{\mathrm{BC} 2}\right)$ treatments increased, whereas that in soils with both saw dust and saw dust biochar treatments $\left(\mathrm{T}_{\mathrm{BM} 3}\right.$ and $\mathrm{T}_{\mathrm{BC} 3}$, respectively) decreased. In the third sampling (i.e. 90 days of incubation), the available $\mathrm{N}$ of all the soils with treatments increased except in the soil with $\mathrm{T}_{\mathrm{BM} 1}$ treatment, that showed a decreasing tendency. 
It is apparent that the available $\mathrm{N}$ of control soil $\left(\mathrm{T}_{\mathrm{C}}\right)$ and all the biochar treated soils followed the same trend as for the total nitrogen. But rice husk (BM1) and rice straw (BM2) treated soils showed an overall declining trend in available $\mathrm{N}$ content. Then available $\mathrm{N}$ of saw dust (BM3) treated soil decreased (at 30 days of incubation), increased (at 60 days of incubation) and again decreased (at 90 days of incubation) (Table 7). The trend of increasing available $\mathrm{N}$ of control soil $\left(\mathrm{T}_{\mathrm{C}}\right)$ and biochar treated soils can

Table 7. Available nitrogen in soil after biochar and biomass applications at different incubation days.

\begin{tabular}{llllllll}
\hline \multirow{2}{*}{$\begin{array}{l}\text { Incubation } \\
\text { days }\end{array}$} & \multicolumn{7}{c}{ Available nitrogen $(\mathrm{mg} / \mathrm{kg})$} \\
\cline { 2 - 7 } & Control & \multicolumn{5}{c}{ Biomass } & \multicolumn{3}{c}{ Biochar } \\
\cline { 2 - 7 } & $\left(\mathrm{T}_{\mathrm{C}}\right)$ & $\mathrm{T}_{\mathrm{BM} 1}$ & $\mathrm{~T}_{\mathrm{BM} 2}$ & $\mathrm{~T}_{\mathrm{BM} 3}$ & $\mathrm{~T}_{\mathrm{BC} 1}$ & $\mathrm{~T}_{\mathrm{BC} 2}$ & $\mathrm{~T}_{\mathrm{BC} 3}$ \\
\hline 30 & 26.16 & 27.21 & 26.16 & 19.88 & 17.79 & 25.12 & 27.21 \\
60 & 27.21 & 23.02 & 19.88 & 27.21 & 26.16 & 27.21 & 27.21 \\
90 & 33.49 & 19.88 & 20.93 & 25.12 & 34.53 & 33.49 & 40.81 \\
\hline
\end{tabular}

be explained by the higher $\mathrm{C} / \mathrm{N}$ ratio. In this experiment, the initial $\mathrm{C} / \mathrm{N}$ ratio of biochars is excessively high (ranging from 63 to 116). It could thus be a reason that the available $\mathrm{N}$ during the first sampling (i.e. 30 days of incubation) was low for biochar treated soils due to immobilization of $\mathrm{N}$. As $\mathrm{C} / \mathrm{N}$ ratio decreased with time $\mathrm{N}$ availability increased in biochar treated soils. However, the available $\mathrm{N}$ for biochar treated soils was higher than that for biomass treated soil. This could be because the $\mathrm{C} / \mathrm{N}$ ratio of biochar treated soils was lower than that of biomass treated soil. $\mathrm{N}$ immobilization after application of fresh biochar is most likely a transient phenomenon, because of the relative small fraction of easily degradable carbohydrates in the biochar (Brunn et al. 2011). After the initial mineralization of this labile C-pool, the $\mathrm{N}$ immobilization can be expected to be negligible (as seen in $\mathrm{C} / \mathrm{N}$ ratio), due to the recalcitrance of the remaining biochar carbon (Brunn et al. 2011).

Available P: The available $\mathrm{P}$ of the soils varied at different incubation days. In the first sampling (i.e. 30 days of incubation), the available $\mathrm{P}$ increased in $\mathrm{T}_{\mathrm{C}}$ and soil treated with, $\mathrm{T}_{\mathrm{BM} 2}$ among the biomass treatments and $\mathrm{T}_{\mathrm{BC}}$ among the biochar treatments, whereas rest treatments caused decrease in available $P$ from the initial background level (i.e. 5.21 $\mathrm{mg} / \mathrm{kg}$ ). In the second sampling (i.e. 60 days of incubation), the available $\mathrm{P}$ in all the soils with treatments increased, where soil treated with rice husk (BC1) showed the maximum available P (i.e. $20.98 \mathrm{mg} / \mathrm{kg}$ ). In the third sampling (i.e. 90 days of incubation), all the soils showed a drastic decline in available $\mathrm{P}$ (Table 8). 
From the Table 8, it is evident that all biomass and biochar treated soils as well as control $\left(\mathrm{T}_{\mathrm{C}}\right)$ showed similar trend in the change in available $\mathrm{P}$ with the incubation days. At 60 days of incubation, the available $\mathrm{P}$ was higher. Besides, the overall $\mathrm{P}$ availability was higher in biochar treated soils rather than biomass treated soil. These could be due to the increase in soil $\mathrm{pH}$ (ranging from $\mathrm{pH} 6.00$ to 6.53) at 60 days of incubation. $\mathrm{P}$

Table 8. Available phosphorus in soil after biochar and biomass applications at different incubation days.

\begin{tabular}{llllllll}
\hline \multirow{2}{*}{$\begin{array}{l}\text { Incubation } \\
\text { days }\end{array}$} & \multicolumn{7}{c}{ Available phosphorus (mg/kg) } \\
\cline { 2 - 8 } & Control & $\mathrm{T}_{\mathrm{BM} 1}$ & $\mathrm{~T}_{\mathrm{BM} 2}$ & $\mathrm{~T}_{\mathrm{BM} 3}$ & $\mathrm{~T}_{\mathrm{BC} 1}$ & $\mathrm{~T}_{\mathrm{BC} 2}$ & $\mathrm{~T}_{\mathrm{BC} 3}$ \\
\cline { 2 - 7 } & $\left(\mathrm{T}_{\mathrm{C}}\right)$ & 4.26 & 6.04 & 4.23 & 5.04 & 4.75 & 5.25 \\
60 & 5.97 & 8.08 & 17.56 & 14.25 & 20.98 & 14.28 & 5.81 \\
60 & 6.77 & 2.85 & 3.02 & 2.07 & 3.96 & 2.92 & 3.95 \\
\hline
\end{tabular}

availability is $\mathrm{pH}$ dependent and at near neutral $\mathrm{pH}, \mathrm{P}$ availability increases (Tisdale et al. 1993). Cheng et al. (2008) demonstrated that fresh biochar has an abundance of anion exchange capacity (AEC) in the acid $\mathrm{pH}$ range, which can initially be in excess of the total CEC of the biochar. So, biochar may alter $\mathrm{P}$ availability by providing anion exchange capacity or by influencing the activity of cations that interact with P (DeLuca et al. 2009). Again, it is possible that the positive exchange sites compete with $\mathrm{Al}$ and $\mathrm{Fe}$ oxides (e.g. gibbsite and goethite, respectively) for sorption of soluble P, similar to that observed for humic and fulvic acids (Sibanda and Young 1986, Hunt et al. 2007).

Available S: After the application of all the treatments, the available $\mathrm{S}$ of the soils varied at different incubation days. In the first sampling (i.e. 30 days of incubation), the available $S$ increased in soil treated with $T_{C}$, and $T_{B M 2}$ and $T_{B M 3}$ among the biomass treatments, whereas rest of the treatments including all the biochar treatments caused decrease in available $S$ in soil from the background level (i.e. $10.02 \mathrm{mg} / \mathrm{kg}$ ). In the second

Table 9. Available sulfur of soil after biochar and biomass applications at different incubation days.

\begin{tabular}{llllllll}
\hline \multirow{2}{*}{$\begin{array}{l}\text { Incubation } \\
\text { days }\end{array}$} & \multicolumn{7}{c}{ Available sulfur $(\mathrm{mg} / \mathrm{kg})$} \\
\cline { 2 - 7 } & Control & $\mathrm{T}_{\mathrm{BM} 1}$ & $\mathrm{~T}_{\mathrm{BM} 2}$ & $\mathrm{~T}_{\mathrm{BM} 3}$ & $\mathrm{~T}_{\mathrm{BC} 1}$ & $\mathrm{~T}_{\mathrm{BC} 2}$ & $\mathrm{~T}_{\mathrm{BC} 3}$ \\
\cline { 2 - 8 } 30 & 12.98 & 3.37 & 39.42 & 25.40 & 3.37 & 1.36 & 3.37 \\
60 & 4.57 & 14.58 & 2.96 & 2.96 & 6.17 & 11.78 & 8.17 \\
90 & 27.65 & 25.27 & 15.76 & 11.01 & 12.02 & 8.29 & 55.16 \\
\hline
\end{tabular}

sampling (i.e. 60 days of incubation), the available $S$ increased in soil treated with $T_{B M 1}$ among the biomass treatments, and all the biochar treated soils, whereas the rest of the treatments including control $\left(\mathrm{T}_{\mathrm{C}}\right)$ caused decrease in available $\mathrm{S}$ in soil. But in the third 
sampling (i.e. 90 days of incubation), the available $S$ in soils with treatments increased, except soils treated with $\mathrm{T}_{\mathrm{BC} 2}$ (Table 9).

From the Table 9, it is apparent that available sulfur in biomass and biochar treated soils and control soil showed inconsistent response during the entire incubation period. Besides, the overall sulfur availability was low. Reason for such behavior could not be found in literature. However, this inconsistent response could be due to temperature of biochar formation where sulfur could be volatilized, or due to the quite lower sulfur content of biomasses and biochars (Table 4). This could also happen due to the presence of less sulfur reducing bacteria or presence of quite a good amount of sulfur-oxidizing bacteria as the soil was slightly acidic. According to DeLuca et al. (2009), sulfur oxidation is carried out by both autotrophic (e.g. Thiobacillus spp.) and heterotrophic organisms by acidophilic Thiobacillus sp. would not be favored by $\mathrm{pH}$ increases induced by the presence of biochar. However, Rondon et al. (2007) suggested that these autotrophic organisms have uniquely high requirements for certain trace elements that are in relatively low concentrations in biochar and are increased in soil when biochar is added. Khan et al. (2014) observed that the abundance of sulphur reducing bacteria was significantly reduced in soils treated with biochars.

Available K: After the application of all the treatments, the available $\mathrm{K}$ of the soils varied at different incubation days. In the first sampling (i.e. 30 days of incubation), the available $\mathrm{K}$ increased in all biomass treated soils, and soils treated with $\mathrm{T}_{\mathrm{BC} 3}$ among the biochar treatments, whereas rest of the treated soils including control soil $\left(\mathrm{T}_{\mathrm{C}}\right)$ caused decrease in available $\mathrm{K}$ in soil from the background level (i.e. $28.87 \mathrm{mg} / \mathrm{kg}$ ). In the second sampling (i.e. 60 days of incubation), the available $\mathrm{K}$ increased in $\mathrm{T}_{\mathrm{C}}$ and in soils treated with, $\mathrm{T}_{\mathrm{BM} 1}$ (among the biomass treatments) and $\mathrm{T}_{\mathrm{BC} 1}$ and $\mathrm{T}_{\mathrm{BC} 3}$ (among the biochar treatments), whereas rest of the treated soils caused a decrease in the available $\mathrm{K}$. In the third sampling (i.e. 90 days of incubation), soils treated with $\mathrm{T}_{\mathrm{BM} 2}$ (among the biomass treatments) and the corresponding biochar treatment, i.e. $\mathrm{T}_{\mathrm{BC} 2}$ caused a slight increase in available $\mathrm{K}$, whereas rest of the treatments showed a decline, and control being stable as 60 days of incubation (i.e. $30.97 \mathrm{mg} / \mathrm{kg}$ ) (Table 10).

Table 10. Available potassium in soil after biochar and biomass applications at different incubation days.

\begin{tabular}{llllllll}
\hline \multirow{2}{*}{$\begin{array}{l}\text { Incubation } \\
\text { days }\end{array}$} & \multicolumn{7}{c}{ Available potassium (mg/kg) } \\
\cline { 2 - 8 } & Control & \multicolumn{5}{c}{ Biomass } & \multicolumn{3}{c}{ Biochar } \\
\cline { 2 - 8 } & $\left(\mathrm{T}_{\mathrm{C}}\right)$ & $\mathrm{T}_{\mathrm{BM} 1}$ & $\mathrm{~T}_{\mathrm{BM} 2}$ & $\mathrm{~T}_{\mathrm{BM} 3}$ & $\mathrm{~T}_{\mathrm{BC} 1}$ & $\mathrm{~T}_{\mathrm{BC} 2}$ & $\mathrm{~T}_{\mathrm{BC} 3}$ \\
\hline 30 & 27.68 & 31.15 & 29.97 & 33.00 & 26.31 & 24.78 & 29.57 \\
60 & 30.97 & 33.92 & 27.21 & 28.27 & 27.90 & 24.63 & 32.14 \\
90 & 30.97 & 27.26 & 28.23 & 26.95 & 25.88 & 24.75 & 23.75 \\
\hline
\end{tabular}


From the Table 10, it is apparent that all biomass and biochar treated soils responded differently compared to the control soil $\left(\mathrm{T}_{\mathrm{C}}\right)$ and the response of the control soil for available $\mathrm{K}$ was almost static. Besides, like available sulfur, the treated soils showed inconsistent response. It is also evident from the above results that the available potassium content of the biomass treated soils was almost higher than that of biochar treated soils. As the CEC of biochar treated soils was higher than that of biomass treated soils, more $\mathrm{K}$ was retained through the exchange process by these soils thereby resulting in less available K. However, Chan et al. (2007) found an increase in the potassium concentration due to biochar application along with green-waste in radish production which he concluded to be due to the high concentrations of the exchangeable potassium found in biochar.

In conclusion, it can be said that as is found in different literatures about the effect of biochars on soil health, the phenomenon is not conclusive, rather diverse which is also apparent in the present study. The carbon sequestration by biochar needs to be further studied vis-à-vis soil nutrients.

\section{References}

Atkinson, C. J., J. D.Fitzgerald, and N. A. Hipps.2010. Potential mechanisms for achieving agricultural benefits from biochar application to temperate soils: A review. Plant Soil 337:1 -18.

Brunn, E. W., H. Hauggaard - Nielson, N. Ibrahim, H. Egsgaard, P.Ambus, P.A. Jensen, and K. Dam - Johansen, 2011. Influence of fast pyrolysis temperature on biochar labile fraction and short - term carbon loss in a loamy soil. Biomass Bioenergy 35:1182 - 1189.

Chan, K.Y., L.Van Zwieten, I.Meszaros, A. Downie, and S. Joseph, 2007. Agronomic values of green waste biochar as a soil amendment. Austra. J. Soil Res. 45(8):629 - 634.

Chan, K.Y., and Z. Xu, 2009. Biochar: Nutrient properties and their enhancement. In: Biochar for environmental management (Eds. Lehmann, J., and Joseph, S.). Earthscan, London, UK. pp. $67-84$.

Chapman, W. L., and E. Walsh, 2007. A Synthesis of Antarctic Temperatures. J. Climate 20:4096 $-4117$.

Cheng, C. H., J. Lehmann, and M. Engelhard, 2008. Natural oxidation of black carbon in soils: Changes in molecular form and surface charge along a climosequence. Geochimica et Cosmochimica ACTA 72:1598 - 1610.

DeLuca, T. H., M.D. MacKenzie, and M. J. Gundale, 2009. Biochar Effects on Soil Nutrient Transformations. In: Biochar for Environmental Management and Technology (Eds. Lehmann, J., and Joseph, S.). Earthscan, London, UK. pp. 251 - 270.

Fowles, M., 2007. Black carbon sequestration as an alternative to bio-energy. Biomass Bioenergy. 31: 26 - 432. 
Hunt, J.F., T.Ohno, Z. He, C.W. Honeycutt, and D. B. Dail, 2007. Inhibition of phosphorus sorption to goethite, gibbsite, and kaolin by fresh and decomposed organic matter. Biol. Fertil. Soil 44:277 - 288.

Huq, S. M. I., and M. D. Alam. 2005. A Handbook on Analyses of Soil, Plant, and Water. BACER-DU, University of Dhaka, Bangladesh. pp. - 246.

Jackson, M. L., 1962. Soil Chemical Analysis. Prentice Hall Inc. Englewood Cliffs. N. J., USA. pp. 1 - 498.

Kerr, R. A., 2001. Bush backs spending for a “global problem”. Science 292:1978.

Khan, T. F., M. M. Ahmed, and S. M. Imamul Huq, 2014. Effects of Biochar on the Abundance of Three Agriculturally Important Soil Bacteria. J. Agric. Chem. and Env., 3: 31-39.

Kluger, J., 2007. Global warming what now? Our feverish planet badly needs a cure. Time Magazine. 9:50 - 109.

Lehmann, J. and M. Rondon, 2006. Biochar soil management on highly weathered soils in the humid tropics. In: Biological Approaches to Sustainable Soil Systems (Ed. Uphoff, N. T.). CRC Press, Boca Raton, FL. pp. 519 - 521.

Lehmann, J., and S. Joseph, 2009. Biochar for environmental management: An introduction. In: Biochar for environmental management: Science and Technology (Eds. Lehmann, J., and Joseph, S.). London , UK. pp. 1 - 12.

Lehmann, J. and S.P. Sohi, 2008. Comment on "Fire - derived charcoal causes loss of forest humus”. Science. 321:1295.

Mahmud, K., M. S. Chowdhury, N. Noor, and S. M. Imamul Huq, 2014. Effects of different sources of biochar application on the emission of a number of gases from soil. Canad. J. Pure \& Appl.Sci. 8(2): 2813-2824.

Motomura, S., 1962. Effect of organic matters on the formation of ferrous iron in soils. Soil Sci. Plant Nutr. 8:20 - 29.

Nigussie, A., E. Kissi, M. Misganaw, and G. Ambaw, 2012. Effect of biochar on soil properties and nutrient uptake of lettuces (Lactuca sativa) grown in Chromium polluted soils. American -Eurasian J. Agric. Environ. Sci. 12(3):369 - 376.

Ponnamperuma, F. N., 1965. In: The mineral Nutrition of the Rice Plant. Johns Hopkins Press, Baltimore, Maryland. pp. 295 - 328.

Rondon, M., J. Lehmann, J. Ramirez, and M. Hurtado, 2007. Biological nitrogen fixation by common beans (Phaseolus bulgaris L.) increases with biochar additions. Biol. Fertil. Soil. 43:699 - 708.

Sibanda, H. M., and S.D.Young, 1986. Competitive adsorption of humus acids and phosphate on goethite, gibbsite and two tropical soils. Eur. J. Soil Sci. 37:197 - 204.

Sohi, S. P., E. Krull, E. Lopez-Capel and R. Bol, 2010. A review of Biochar and its Use and Function in Soil. In: Advances in Agronomy. Elsevier Academic Press Inc., ISSN 0065-2213, San Diego, CA-92101-4495, USA. pp. 47 - 82. 
Steinbeiss, S., G. Gleixner and M.Antonietti, 2009. Effect of biochar amendment on soil carbon balance and soil microbial activity. Soil Biol. Biochem. 30:1 - 10.

Steiner, C., 2010. Biochar in Agricultural and Forestry Application. In: Biochar from agricultural and forestry residues - A complimentary use of "Waste" Biomass. U. S. - Focused Biochar Report: Assessment of Biochar's Benefit for the United States of Amaerica, Colorado, USA. pp. 7.

Steiner, C., W.G. Teixeira, J. Lehmann, T. Nehls, J.L.V. De Macedo, W.E.H. Blum and W. Zech. 2007. Long term effects of manure, charcoal and mineral fertilization oncrop production and fertility on a highly weathered Central Amazonian upland soil. Plant and Soil 291:275 - 290.

Tisdale, S. L., W.L. Nelson, J.D. Beaton, and J.L. Havlin, 1993. Soil Fertility and Fertilizers. 5th ed. Pearson Education, New Jersey, USA.

Van Zwieten, L., S. Kimber, S. Morris, A. Downie, E. Berger, J. Rust, and C. Scheer, 2010. Influence of biochars on flux of $\mathrm{N}_{2} \mathrm{O}$ and $\mathrm{CO}_{2}$ from Ferrosol. Soil Res. 48(7):555 - 568.

Wardle, D. A., C.Nilsson, and O. Zackrisson, 2008a. Fire - derived charcoal Causes Loss of Forest Humus. Science. 320 (5876):629. doi: 10.1126/science.

Wardle, D. A., C. Nilsson, and O. Zackrisson, 2008b. Response to comment on "Fire - derived charcoal Causes Loss of Forest Humus”. Science. 321.

Web 1: http://www.fao.org/docrep/009/a0100e/a0100e05.htm

Web 2: http://www.apn-gcr.org/resources/archive/files/1d461f5fc45b0711342ef8c2b1e1030c.pdf

Woolf, D., 2008. Biochar as a soil amendment: A review of the environmental implications. http://orgprints.org/13268/1/Biochar_as_a_soil_amendment_-_a_review.pdf

Woolf, D., Amonette, James E., Street-Perrott, F. A., Lehamnn, J., and Joseph, S. 2010. Sustainable biochar to mitigate global climate change. Nat. Commun. 1:56.

(Manuscript received on 04 June, 2014; revised on 08 July, 2014) 